\title{
Nucleus accumbens as a stereotactic target for the treatment of addictions in humans: a literature review
}

\author{
Michał Sobstyl $^{1}$, Anna Kupryjaniuk ${ }^{1}$, Paweł Mierzejewski \\ ${ }^{1}$ Department of Neurosurgery, Institute of Psychiatry and Neurology, Warsaw, Poland \\ ${ }^{2}$ Department of Pharmacology, Institute of Psychiatry and Neurology, Warsaw, Poland
}

\begin{abstract}
Introduction: Deep brain stimulation (DBS) has achieved substantial success as a treatment for movement disorders such as Parkinson's Disease (PD), essential tremor (ET), and dystonia. More recently, a limited number of basic and clinical studies have indicated that DBS of the nucleus accumbens (NAC) and other neighbouring structures of the reward circuit may be an effective intervention for patients with treatment-refractory addiction.

Material and methods: We performed a structured literature review of human studies of DBS for addiction outlining the clinical efficacy and adverse events. We found 14 human studies targeting mostly the NAc with neighbouring structures such as anterior limb of the internal capsule (ALIC). Five studies including 12 patients reported the outcomes for alcohol dependence. Nine studies including 18 patients reported the outcomes for addictions to various psychoactive substances. The most common indication was addiction to heroin, found in 13 patients, followed by methamphetamine, 3 patients, cocaine, one patient, and polysubstance drug abuse in one patient.

Conclusions: The limited clinical data available indicates that DBS may be a promising therapeutic modality for the treatment of intractable addiction. In general, the safety profile of DBS in patients with addiction is good. Based on the data published in the literature, the NAc is the most often targeted, and is probably the most effective, structure of the reward circuit in the treatment of addiction in humans. Given the ever-expanding understanding of the psychosurgery of addiction, DBS could in the future be a treatment option for patients suffering from intractable addictive disorders.
\end{abstract}

Key words: addiction, alcohol dependence, anterior limb of the internal capsule, deep brain stimulation

(Neurol Neurochir Pol 2021; 55 (5): 440-449)

\section{Introduction}

Drug addiction, also called substance use disorder, is a disease that affects a person's brain and behaviour and leads to an inability to control the use of a legal or illegal drug or medication. Drug addiction is a complex, chronic, relapsing illness [1]. Addictive disorders are among the most common mental disorders in developed countries. Drug addiction is composed of physical and psychosocial dependence. Physical dependence is related to the withdrawal syndrome with coexistent noradrenergic hyperactivity in the locus coeruleus. The treatment of physical dependence (withdrawal syndrome) may be successfully achieved by means of substantive therapies or other therapies such as dopamine transporter blockers, non-dopaminergic drugs, or cannabinoid antagonists. Psychological dependence has been closely associated with drug-seeking behaviour which correlates with dopaminergic activity in the mesolimbic pathway, especially in the nucleus accumbens (NAc) [2].

The treatment of psychological dependence is much more difficult than physiological detoxification and elimination of withdrawal syndrome. Psychological dependence can be treated by a drug substitute therapy, cognitive-behavioural therapy (CBT), and surgical treatment. Surgical treatment, mainly the ablative neuropsychiatric procedures for drug addiction, has been utilised in a large cohort of patients since

Address for correspondence: Anna Kupryjaniuk, Department of Neurosurgery, Institute of Psychiatry and Neurology, Sobieskiego 9, 02-957, Warsaw,

Poland; e-mail: kupryjaniukanna@gmail.com

Received: 30.05.2021 Accepted: 10.08.2021 Early publication date: 11.10.2021

This article is available in open access under Creative Common Attribution-Non-Commercial-No Derivatives 4.0 International (CC BY-NC-ND 4.0) license, allowing to download articles and share them with others as long as they credit the authors and the publisher, but without permission to change them in any way or use them commercially. 
the 1970s. Ablative procedures have been largely replaced in recent years by deep brain stimulation (DBS) procedures not only for movement disorders, but also for neuropsychiatric indications such as obsessive-compulsive disorder (OCD), major depressive disorder (MDD), Tourette's Syndrome, and drug abuse and addiction [3-7].

The primary aim of this review was to present the clinical outcomes of nucleus accumbens (NAc) DBS for alcohol and psychoactive drug addictions. We also present the role of the NAc in the psychological mechanism of drug addiction.

\section{Nucleus accumbens as target within reward system for addiction}

Recent advances in neuroimaging have brought about better understanding of the functions of the reward system in humans and its disturbances in addicted patients [8]. The most prominent neuroanatomically defined structures of the reward pathway include the anterior cingulate cortex (AAC), the orbitofrontal cortex, the NAc within the ventral striatum (VS), and the ventral tegmental area (VTA) [9].

The reward pathway, sometimes referred to as the mesolimbic pathway, connects the VTA in the midbrain to the VS of the basal ganglia in the forebrain. The release of dopamine from the mesolimbic pathway into the NAc regulates motivation and desire for rewarding stimuli and facilitates reinforcement and reward-related motor function learning [10]. Dysregulation of the mesolimbic pathway and its output neurons in the NAc plays a significant role in the development and maintenance of an addiction [11].

The NAc is subdivided into limbic and motor subregions known as the NAc shell and the NAc core. The shell of the NAc occupies its medial, ventral, and lateral parts, whereas the core occupies its central and dorsal parts. The medium spiny neurons in the NAc receive input from both the dopaminergic neurons of the VTA and the glutamatergic neurons of the hippocampus, amygdala, and medial prefrontal cortex. When they are activated by these inputs, the medium spiny neurons' projections release GABA onto the ventral striatum. The NAc attains a central position between limbic and mesolimbic dopaminergic structures, basal ganglia, and limbic prefrontal cortices. This central position of the NAc influences reward-related and drug self-administration behaviours, as well as motivation, learning and adaptive behaviours [10,11].

Commonly abused substances, such as cocaine, alcohol, and nicotine, have been shown to increase extracellular levels of dopamine within the mesolimbic pathway, preferentially within the NAc [12]. These dopaminergic activations of the mesolimbic pathway are accompanied by the perception of reward. This stimulus-reward association shows a resistance to extinction and creates an increased motivation to repeat the same behaviour that caused it. Neurosurgical procedures directed at the mesolimbic system have reduced or modulated NAc activity. These have included stereotactic ablation of the
NAc with the VS, and more recently implantation of DBS electrodes into the NAc to treat intractable addictive disorders.

\section{Ablative surgery and DBS procedures for addictive disorders}

Surgery as treatment for drug addiction has been carried out since the 1970s, when many patients were addicted to heroin and other drugs as partial consequences of the 'hippie' revolution. The failed attempts of substitute therapy or CBT for drug addicts, and extremely high drug relapse rates, have generated interest in the ablative neurosurgical procedures done at that time for psychiatric disorders and drug addictions.

One of the first ablative stereotactic operations for the treatment of various psychiatric illnesses, including mood disorders, anxiety disorders and OCD, was cingulotomy [13]. Cingulotomy was shown to be not only effective for psychiatric conditions, but also for chronic intractable pain in patients addicted to narcotics [14]. Foltz et al. presented in 16 patients, (11 patients had bilateral and five had unilateral lesions in cingulum) that all 14 addicted to narcotics required no more drugs 72 hours after unilateral or bilateral cingulotomy [15]. In 1978, Kanaka and Balasubramaniam reported the clinical outcomes of $73 \mathrm{pa}-$ tients with drug addiction treated with anterior cingulotomy [16]. They analysed the results of surgical treatment of these 73 patients with morphine, pethidine and alcohol addictions. Follow-up varied from 1-6 years. According to the authors, excellent results were achieved in $60-80 \%$ of patients [16].

The largest study, of 348 addicted patients after bilateral cingulotomy, was reported by Medvedev et al. At 2-years follow-up, 187 patients had complete cessation of drug use and termination of drug craving [17]. Stereotactic lesions targeting ventromedial hypothalamic nucleus or hypothalamus have also been applied in the neurosurgical treatment of drug addiction, but with only limited clinical value [18]. The main limitation of the abovementioned studies was the lack of precision of lesion placement when compared to neurosurgical procedures for alcohol or drug addiction that are performed today. Direct targeting with magnetic resonance imaging (MRI) has enabled the detailed documentation of lesion placement in the NAc or post-operative accurate verification of the position of a DBS electrode in the NAc.

In 2003, Gao et al. presented encouraging results in 28 patients with NAc ablation for opiate addiction [19]. Over the ensuing months, the relapse rates increased and at 6 months reached $58 \%$. The side effects included temporary memory loss in four patients and personality changes in two. The authors stated that the side effects apparently did not affect the patients' daily functioning or intellectual ability. These results sparked the rise of NAc ablations for addicted patients in China. It was estimated that around 1,000 NAc bilateral ablations had been performed by 2004. Well-controlled clinical trials were not done to support the claim that NAc ablation was a safe and effective neurosurgical treatment for drug addiction in humans. As a consequence, the widespread clinical use of NAc ablation was halted by Chinass Ministry of Health. 
Table 1. Case reports and pilot studies showing effects of bilateral NAC DBS in treatment of severe alcohol dependency. In all case reports and case series for alcohol addiction, NAc was chosen as a stereotactic target

\begin{tabular}{|c|c|c|c|c|c|c|c|}
\hline $\begin{array}{l}\text { Authors } \\
\text { and year } \\
\text { of publication }\end{array}$ & $\begin{array}{l}\text { Number } \\
\text { of } \\
\text { patients }\end{array}$ & $\begin{array}{l}\text { Study } \\
\text { design }\end{array}$ & $\begin{array}{l}\text { Stimulation } \\
\text { parameters }\end{array}$ & $\begin{array}{l}\text { Prevailed indi- } \\
\text { cation for DBS } \\
\text { procedure }\end{array}$ & Outcomes & $\begin{array}{l}\text { Follow- } \\
\text {-up }\end{array}$ & $\begin{array}{l}\text { Side effects } \\
\text { of stimulation }\end{array}$ \\
\hline $\begin{array}{l}\text { Kuhn et al. } 2007 \\
\text { [20] }\end{array}$ & 1 & $\begin{array}{l}\text { Case } \\
\text { report }\end{array}$ & $\begin{array}{l}3 \mathrm{~V}, \\
90 \mu \mathrm{sec}, \\
130 \mathrm{~Hz}\end{array}$ & $\begin{array}{l}\text { Severe anxiety } \\
\text { disorder, secondary } \\
\text { depressive disorder } \\
\text { and comorbid alco- } \\
\text { hol dependency }\end{array}$ & $\begin{array}{l}\text { Slight reduction of } \\
\text { anxiety disorder, no } \\
\text { effect on depression, } \\
\text { remarkable change in } \\
\text { alcohol dependency }\end{array}$ & 1 year & Not reported \\
\hline $\begin{array}{l}\text { Mullner et al. } \\
2009 \text { [21] }\end{array}$ & 3 & $\begin{array}{l}\text { Case } \\
\text { series }\end{array}$ & $\begin{array}{l}3.5-4.5 \mathrm{~V}, 90 \\
\mu \mathrm{sec}, 130 \mathrm{~Hz}\end{array}$ & $\begin{array}{l}\text { Primary alcohol } \\
\text { dependency }\end{array}$ & $\begin{array}{l}2 \text { patients remained } \\
\text { abstinent, } 1 \text { patient } \\
\text { showed reduction in } \\
\text { alcohol dependency }\end{array}$ & 1 year & $\begin{array}{l}\text { Transient hypomanic } \\
\text { period of } 1 \text { week's } \\
\text { duration in } 1 \text { patient }\end{array}$ \\
\hline $\begin{array}{l}\text { Kuhn et al. } 2011 \\
\text { [22] }\end{array}$ & 1 & $\begin{array}{l}\text { Case } \\
\text { report }\end{array}$ & $\begin{array}{l}5.5 \mathrm{~V}, 120 \\
\mu \mathrm{sec}, 130 \mathrm{~Hz}\end{array}$ & $\begin{array}{l}\text { Primary alcohol } \\
\text { dependency }\end{array}$ & $\begin{array}{l}\text { Complete } \\
\text { cessation of alcohol } \\
\text { dependency }\end{array}$ & 1 year & Not reported \\
\hline $\begin{array}{l}\text { Voges et al. } 2013 \\
\text { [24] }\end{array}$ & 5 & $\begin{array}{l}\text { Pilot } \\
\text { study } \\
\text { Case } \\
\text { series }\end{array}$ & $\begin{array}{l}4.5 \mathrm{~V}, 120 \\
\mu \mathrm{sec}, 130 \mathrm{~Hz}\end{array}$ & $\begin{array}{l}\text { Primary alcohol } \\
\text { dependency }\end{array}$ & $\begin{array}{l}2 \text { patients remained } \\
\text { abstinent, } 3 \text { relapsed } \\
\text { with reduced alcohol } \\
\text { consumption }\end{array}$ & $\begin{array}{l}2 \text { years } \\
\text { average } \\
\text { follow-up } \\
\text { to } 38 \\
\text { months }\end{array}$ & $\begin{array}{l}\text { Transient hypomania. } \\
\text { One case of electrode } \\
\text { dislocation }\end{array}$ \\
\hline $\begin{array}{l}\text { Mullner at al. } \\
2016 \text { [25] }\end{array}$ & $\begin{array}{l}5 \text { (3 } \\
\text { patients } \\
\text { included } \\
\text { from } \\
\text { previous } \\
\text { publica- } \\
\text { tion) }\end{array}$ & $\begin{array}{l}\text { Pilot } \\
\text { study } \\
\text { Case } \\
\text { series }\end{array}$ & $\begin{array}{l}3.5-4.5 \mathrm{~V}, 90 \\
\mu \mathrm{sec}, 130 \mathrm{~Hz}\end{array}$ & $\begin{array}{l}\text { Primary alcohol } \\
\text { dependency }\end{array}$ & $\begin{array}{l}\text { All patients reported } \\
\text { persistent disappe- } \\
\text { arance of craving, } \\
2 \text { patients remained } \\
\text { abstinent for } 7 \text { years } \\
\text { and } 3 \text { patients showed } \\
\text { a marked reduction of } \\
\text { alcohol consumption }\end{array}$ & $\begin{array}{l}\text { Follow-up } \\
\text { to } 8 \text { years }\end{array}$ & $\begin{array}{l}\text { No patient reported } \\
\text { any negative overall } \\
\text { psychological } \\
\text { well-being or psycho- } \\
\text { pathological symp- } \\
\text { toms due to DBS }\end{array}$ \\
\hline
\end{tabular}

$\mathrm{NAc}$ - nucleus accumbens; $\mathrm{V}$ - volts; $\mu \mathrm{sec}-$ microseconds; $\mathrm{Hz}$ - frequency

Ablative surgery has in recent years been replaced by DBS procedures in mentally ill patients. Patients with neurological and psychiatric disorders who have undergone DBS procedures with comorbid addictive disorders have also noticed improvements in addictive behaviours towards alcohol, nicotine or psychoactive drugs.

\section{DBS for alcohol addiction}

In 2007, Kuhn et al. presented the first patient with severe anxiety disorder including agoraphobia and secondary depressive disorder who also had alcohol dependence [20]. After bilateral NAc DBS at 1-year follow-up, despite the lack of desired improvement in anxiety, the authors observed a remarkable, although not primarily intended, alleviation of the patient's comorbid alcohol dependency. This case demonstrated the extremely effective treatment of alcohol dependency by means of bilateral NAc DBS [20].

Müllner et al. also confirmed the efficacy of NAc DBS in three alcohol-dependent patients [21]. At 1-year follow-up, two patients remained abstinent, while the third showed a remarkable reduction in the number of days on which he drank, and none had any significant adverse effects [21]. Another case of severe alcohol dependence with psychiatric comorbidities was presented by Kuhn et al. in 2011 [22]. The authors noted that the NAc DBS normalised addictive behaviour and craving.
The authors concluded that their case supports the hypothesis that DBS of the NAc could have a positive effect on addiction through normalisation of the craving associated with anterior mid-cingulate cortex (aMCC) functioning [22] .

Also, Voges et al. presented five patients treated off-label by bilateral NAc DBS for severe alcohol addiction with an average follow-up of 38 months [24]. All patients experienced significant and ongoing improvement of craving. Two patients remained completely abstinent for more than four years. These authors assessed not only the clinical efficacy of bilateral NAc DBS, but also investigated recording of local field potentials from the target area and surface electroencephalography (EEG) [24]. Subsequently, Müllner et al. reported on the long-term clinical outcome (up to 8 years) of five patients who received bilateral NAc DBS to treat long-lasting and treatment-resistant alcohol addiction [25]. All patients reported a complete absence of craving for alcohol; two patients remained abstinent for seven years and the other three patients showed a marked reduction in their alcohol consumption. Table 1 sets out the clinical outcomes of DBS procedures in patients with alcohol dependency.

\section{DBS for opiate addiction}

The first report of NAc DBS for heroin addiction was presented by Zhou et al. [26]. The patient after surgery with a 6-year follow-up was relapse-free, with improvements in his 
anxiety and depression. An additional case of a heroin-addicted patient was presented by Valencia-Alfonso [27]. Bilateral NAc DBS produced a decrease of heroin usage and craving over a 6-month postoperative period [26]. Kuhn et al. presented two additional patients with heroin addiction who achieved decreased heroin consumption with amelioration of depressive and anxiety symptoms and an increase in their subjectively perceived quality of life [28].

The largest study so far reporting the outcomes of NAc DBS for eight heroin-addicted patients was presented by Chen et al. [29]. DBS electrodes were implanted through the anterior limb of internal capsule (ALIC) into the NAc. Five patients were abstinent for more than three years, two relapsed after abstaining for six months, and one was lost to follow-up at three months. Simultaneous DBS of the NAc and ALIC improved the quality of life, alleviated psychiatric symptoms, and increased glucose metabolism in addiction-related brain regions revealed by positron emission tomography (PET) studies.

Zhang at al. presented a case of primary opioid addiction treated by bilateral stimulation of ventral capsule (VC)/VS. In the postoperative period, a mild hypomanic episode forced lowering of the stimulation parameters, which resulted in increased cravings and repeated relapses. The patient fatally overdosed on heroin three months after the initial surgery [30].

\section{DBS for cocaine addiction}

The first case report of a patient with cocaine addiction was presented by Gonzales-Ferreira [31]. DBS electrodes were placed in the posteromedial part of the NAc neighbouring the bed nucleus of stria terminalis (BNST). Six months after the surgery, the use of cocaine and craving were markedly reduced. At 2-years follow-up, there was still improvement in cocaine addiction, but this was a smaller improvement than that witnessed at six months postoperatively [31].

\section{DBS for methamphetamine/amphetamine (MA/A) addiction}

Zhang et al. described a methamphetamine-addicted patient after DBS of the NAc and the VC without co-morbid psychiatric and substance-use disorders [31]. One year after surgery, the patient had become methamphetamine-free and his social functioning had improved. Ge et al. reported two additional patients with MA addiction [32]. At the final follow-up (ranging from 1.5 to 2.5 years) one patient was MA abstinent, but the other patient did not respond and subsequently relapsed. This discrepancy of clinical outcomes was attributed to misplaced DBS leads in the other patient [32]. A recently published case has featured multidrug addiction combining NAc DBS with anterior capsulotomy [33]. After placing radiofrequency lesions bilaterally in the anterior capsule, the DBS leads were implanted into the NAc. This patient had no drug cravings and had stopped using drugs at 12 months follow-up. Moreover, the patient's comorbid depression and anxiety showed progressive improvements during the follow-up. The patient had no adverse events related to the combined surgery, and also showed improvements in memory, learning, and cognitive functions.

According to these authors, the excellent results of combined simultaneous ablative and DBS lead implantations for drug addiction with comorbid psychiatric problems should prompt larger well-controlled clinical studies [33]. Table 2 sets out the clinical outcomes of DBS procedures in patients with various dependencies to psychoactive drugs.

\section{Inclusion and exclusion criteria for DBS in patients with addictions}

The worldwide experience in DBS for addiction is limited, and there are no definitive guidelines on patient selection criteria. Some authors have formulated protocols for the use of DBS in addiction to alcohol or psychoactive substances [20, $23,25,30-33]$. In all of the proposed studies, the main inclusion criterion is a primary diagnosis of addiction according to the Diagnostic and Statistical Manual of Mental Disorders, $5^{\text {th }}$ edition, and the International Classification of Diseases, $10^{\text {th }}$ edition. Qualification for DBS should be carried out by a psychiatrist who has experience in treating addicted patients. Furthermore, the whole procedure should assume the presence of a multidisciplinary team, including a psychiatrist and a neuropsychologist. Moreover, a neurosurgeon and a psychiatrist should be involved in programming the device. There are separate specific inclusion criteria for alcohol addictionand for different drug addictions.

Patients with alcohol addiction should fulfill the following criteria: age 25-60 years, inpatient detoxification with at least two weeks of abstinence before surgery, and the presence of alcoholism for at least 10 years [21]. Patients should try at least two long-term inpatient therapies of at least six months in total with at least one anticraving medication [21]. Patients with drug addictions should meet the following inclusion criteria: age 18-50 years, addiction to psychoactive drugs for at least three years, and at least three relapses with previous conservative treatments including ineffective substitute medication therapies [28].

Patients' cravings for alcohol or drugs have a profound influence on their health and severely affect the quality of their lives and the lives of their family members [23, 25, 30-33]. The final important issue regarding the inclusion criteria is that the consequences of the procedure are understood by the patient and his or her family member in order for an informed choice without coercion to be made and written informed consent for the procedure to be given $[23,28]$. A reasonable amount of time should be given in which the patient and their family can fully consider the benefits and risks before signing a written informed consent.

Such patients must have a suitable living environment and sufficient postoperative care and support to participate in an early postoperative stimulation settings optimisation period, as well as in the scheduled follow-up visits postoperatively. 
Table 2. Case reports and pilot studies showing effects of bilateral NAC DBS or combination of NAc and ALIC DBS in treatment of severe drug addiction including heroin, cocaine, methamphetamine and benzodiazepines

\begin{tabular}{|c|c|c|c|c|c|c|c|c|}
\hline $\begin{array}{l}\text { Authors } \\
\text { and year } \\
\text { of publica- } \\
\text { tion }\end{array}$ & $\begin{array}{l}\text { Num- } \\
\text { ber } \\
\text { of } \\
\text { patients }\end{array}$ & $\begin{array}{l}\text { Study } \\
\text { design }\end{array}$ & $\begin{array}{l}\text { Stereotactic tar- } \\
\text { get/targets }\end{array}$ & $\begin{array}{l}\text { Stimulation } \\
\text { parameters }\end{array}$ & $\begin{array}{l}\text { Prevailed indi- } \\
\text { cation for DBS } \\
\text { procedure }\end{array}$ & Outcomes & Follow-up & $\begin{array}{l}\text { Side effects of } \\
\text { stimulation }\end{array}$ \\
\hline $\begin{array}{l}\text { Zhou et al. } \\
2011 \text { [25] }\end{array}$ & 1 & $\begin{array}{l}\text { Case } \\
\text { report }\end{array}$ & $\begin{array}{l}\text { Bilateral stimula- } \\
\text { tion of NAC }\end{array}$ & $\begin{array}{l}2.5 \mathrm{~V}, 90 \mu \mathrm{sec}, \\
125 \mathrm{~Hz}\end{array}$ & $\begin{array}{l}\text { Primary heroin } \\
\text { addiction }\end{array}$ & $\begin{array}{l}\text { Complete drug } \\
\text { addiction wit- } \\
\text { hdrawal for } \\
6 \text { years }\end{array}$ & $\begin{array}{l}\text { For } 2.5 \\
\text { years with } \\
\text { stimulation, } \\
\text { up to } 6 \text { ye- } \\
\text { ars without } \\
\text { stimulation }\end{array}$ & $\begin{array}{l}\text { Transient mild } \\
\text { confusion and urinary } \\
\text { incontinence. } \\
\text { On request of family, } \\
\text { pulse generator was } \\
\text { turned off at } 2.5 \text { years } \\
\text { after surgery, and at } \\
3 \text { years removed }\end{array}$ \\
\hline $\begin{array}{l}\text { Valencia- } \\
\text {-Alfonso et } \\
\text { al. } 2012 \text { [26] }\end{array}$ & 1 & $\begin{array}{l}\text { Case } \\
\text { report }\end{array}$ & $\begin{array}{l}\text { Bilateral stimulation } \\
\text { of NAc and ante- } \\
\text { rior limb of internal } \\
\text { capsule (ALIC) }\end{array}$ & $\begin{array}{l}3.5 \mathrm{~V}, 90 \mu \mathrm{sec} \\
180 \mathrm{~Hz}\end{array}$ & $\begin{array}{l}\text { Primary heroin } \\
\text { addiction }\end{array}$ & $\begin{array}{l}6 \text { months drug- } \\
\text {-free except for } \\
14 \text { days relapse }\end{array}$ & 6 months & Not reported \\
\hline $\begin{array}{l}\text { Kuhn et al. } \\
2014 \text { [27] }\end{array}$ & 2 & $\begin{array}{l}\text { Case } \\
\text { series }\end{array}$ & $\begin{array}{l}\text { Bilateral stimula- } \\
\text { tion of NAC }\end{array}$ & $\begin{array}{l}4.5-5 \mathrm{~V} \\
90-120 \mu \mathrm{sec} \\
140-150 \mathrm{~Hz}\end{array}$ & $\begin{array}{l}\text { Primary heroin } \\
\text { addiction. } \\
\text { Secondary ad- } \\
\text { dictions included } \\
\text { amphetamines, } \\
\text { alcohol, benzo- } \\
\text { diazepines, anxie- } \\
\text { ty and depression }\end{array}$ & $\begin{array}{l}\text { Both patients } \\
\text { abandoned hero- } \\
\text { in use, improve- } \\
\text { ments in anxiety } \\
\text { and depressive } \\
\text { symptoms }\end{array}$ & 2 years & $\begin{array}{l}1 \text { postoperative } \\
\text { epileptic seizure in } \\
\text { patient with previous } \\
\text { epilepsy }\end{array}$ \\
\hline $\begin{array}{l}\text { Chen at al. } \\
2018 \text { [28] }\end{array}$ & 8 & $\begin{array}{l}\text { Open } \\
\text { label pilot } \\
\text { study }\end{array}$ & $\begin{array}{l}\text { Bilateral stimula- } \\
\text { tion of NAC and } \\
\text { ALIC }\end{array}$ & $\begin{array}{l}1.5-7 \mathrm{~V} \\
150-240 \mu \mathrm{sec} \\
130-185 \mathrm{~Hz}\end{array}$ & $\begin{array}{l}\text { Primary heroin } \\
\text { addiction }\end{array}$ & $\begin{array}{l}5 \text { patients abs- } \\
\text { tinent for more } \\
\text { than } 3 \text { years, } \\
2 \text { patients } \\
\text { relapsed after } 6 \\
\text { months, } 1 \text { patient } \\
\text { lost to follow-up } \\
\text { after } 3 \text { months }\end{array}$ & 2 years & $\begin{array}{l}1 \text { patient had clinically- } \\
\text {-silent haemorrhage } \\
\text { at DBS lead tip. } \\
\text { Stimulation-related } \\
\text { transient adverse } \\
\text { events included } \\
\text { dizziness, agitation, } \\
\text { irritability, sweating. } \\
1 \text { case of slight memo- } \\
\text { ry decline }\end{array}$ \\
\hline $\begin{array}{l}\text { Zhang at al. } \\
2018 \text { [29] }\end{array}$ & 1 & $\begin{array}{l}\text { Case } \\
\text { report }\end{array}$ & $\begin{array}{l}\text { Bilateral stimula- } \\
\text { tion of VC/VS }\end{array}$ & $\begin{array}{l}3.5 \mathrm{~V}, 90 \mu \mathrm{s}, \\
130 \mathrm{~Hz}\end{array}$ & $\begin{array}{l}\text { Primary heroin } \\
\text { addiction }\end{array}$ & $\begin{array}{l}\text { Reduced opioid } \\
\text { cravings and } \\
\text { decreased } \\
\text { discomfort }\end{array}$ & 12 moths & $\begin{array}{l}\text { Transient hypomania } \\
\text { due to stimulation } \\
\text { settings increase. } \\
\text { Death } 3 \text { months after } \\
\text { surgery due to heroin } \\
\text { overdose }\end{array}$ \\
\hline $\begin{array}{l}\text { Gonzales- } \\
\text {-Ferreira et } \\
\text { al. } 2016 \text { [30] }\end{array}$ & 1 & $\begin{array}{l}\text { Case re- } \\
\text { port with } \\
\text { double- } \\
\text {-blind ran- } \\
\text { domised } \\
\text { control }\end{array}$ & $\begin{array}{l}\text { Bilateral stimula- } \\
\text { tion of postero- } \\
\text {-medial part of NAc } \\
\text { with neighbouring } \\
\text { BNST }\end{array}$ & $\begin{array}{l}2.5-4 \mathrm{~V} \\
150 \mu \mathrm{sec} \\
150 \mathrm{~Hz}\end{array}$ & $\begin{array}{l}\text { Primarycocaine } \\
\text { addiction, } \\
\text { secondary addic- } \\
\text { tions to heroin, } \\
\text { cannabis, alcohol }\end{array}$ & $\begin{array}{l}\text { At } 2,5 \text { years } \\
\text { follow-up, there } \\
\text { was still improve- } \\
\text { ment in cocaine } \\
\text { addiction, but it } \\
\text { was smaller than } \\
\text { at } 6 \text { months }\end{array}$ & 2.5 years & $\begin{array}{l}\text { Transient stimulation } \\
\text { induced unpleasant } \\
\text { warmness, sweating } \\
\text { and flushing }\end{array}$ \\
\hline $\begin{array}{l}\text { Zhang et al. } \\
2019 \text { [31] }\end{array}$ & 1 & $\begin{array}{l}\text { Case } \\
\text { report }\end{array}$ & $\begin{array}{l}\text { Bilateral stimula- } \\
\text { tion of NAc and } \\
\text { ventral capsule }\end{array}$ & Not reported & $\begin{array}{l}\text { Primary } \\
\text { methamphetami- } \\
\text { ne addiction }\end{array}$ & $\begin{array}{l}\text { Complete } \\
\text { cessation of } \\
\text { methamphetami- } \\
\text { ne addiction }\end{array}$ & 1 year & Not reported \\
\hline $\begin{array}{l}\text { Ge et al. } 2019 \\
{[32]}\end{array}$ & 2 & $\begin{array}{l}\text { Case } \\
\text { series }\end{array}$ & $\begin{array}{l}\text { Bilateral stimula- } \\
\text { tion of NAC }\end{array}$ & $\begin{array}{l}2.5-3.3 \mathrm{~V} \\
210-240 \mu \mathrm{sec}, \\
150-165 \mathrm{~Hz}\end{array}$ & $\begin{array}{l}\text { Primary } \\
\text { methampheta- } \\
\text { mine } \\
\text { addiction }\end{array}$ & $\begin{array}{l}\text { First patient } \\
\text { experienced } \\
\text { complete cessa- } \\
\text { tion of addiction, } \\
\text { second patient } \\
\text { failed due to DBS } \\
\text { lead deviation }\end{array}$ & 2 years & $\begin{array}{l}\text { Lead deviation caused } \\
\text { failure of NAc DBS re- } \\
\text { sulting in hypomania } \\
\text { and anxiety }\end{array}$ \\
\hline $\begin{array}{l}\text { Zhu et al. } \\
2019 \text { [33] }\end{array}$ & 1 & $\begin{array}{l}\text { Case } \\
\text { report }\end{array}$ & $\begin{array}{l}\text { Bilateral stimu- } \\
\text { lation of NAC } \\
\text { combined with } \\
\text { capsulotomy }\end{array}$ & $\begin{array}{l}2.7 \mathrm{~V} \\
90 \mu \mathrm{sec} \\
145-160 \mathrm{~Hz}\end{array}$ & $\begin{array}{l}\text { Polysubstance } \\
\text { use disorder } \\
\text { (bucinnazine, } \\
\text { morphine, } \\
\text { hypnotics) }\end{array}$ & $\begin{array}{l}\text { Cessation of all } \\
\text { drug cravings } \\
\text { and drug } \\
\text { addiction }\end{array}$ & 1 year & Not reported \\
\hline
\end{tabular}

ALIL — anterior limb of internal capsule; BNST — bed nucleus of stria terminalis; NAc — nucleus accumbens; VS/VC — ventral striatum/ventral capsule 
Moreover, the local ethics committee and the committee for neurosurgery for psychiatric disorders should review each case individually, and decide whether an addicted patient is suitable for a DBS procedure.

Based on the scientific literature, this is a list of the most frequently described criteria that exclude addicted patients from the DBS procedure: a positive history of withdrawal seizure during pharmacological detoxification for alcohol dependence; an active psychiatric disorder such as schizophrenia; a history of psychosis; active bipolar disorder; and an antisocial personality disorder. Patients with structural changes visible on MRI should be excluded from undergoing DBS surgery. In addition, contraindications for MRI examinations, such as the presence of metal or of a pacemaker, and pregnancy, are exclusion criteria for DBS. Mental retardation or mental handicap is regarded as an exclusion criterion. Presurgically confirmed dementia by neuropsychological tests should be regarded as an exclusion criterion. An IQ in intelligence tests of less than 80 also remains an exclusion criterion. Inability to understand the procedure, lack of cooperation (e.g. noncompliance with scheduled follow-up visits), and inability to provide written informed consent constitute additional exclusion criteria. The abovementioned inclusion/exclusion criteria protocol may promote DBS procedures for alcohol and drug addictions $[21,23,28]$.

\section{A proposal to qualify patients with addictions for a DBS procedure}

We present our proposal to qualify patients with addictions based on the current knowledge in this field.

As the main qualification criterion, we propose that a psychiatrist diagnoses the presence of addiction resistant to pharmacological treatment. Psychotherapeutic measures (including addiction therapy) should have been undertaken, which did not bring about the desired therapeutic effect. There should have been at least 10 years of alcohol dependence and/or at least three years of addiction to psychoactive substances. The prognosis without surgery must be unfavourable. The patient must make informed constent to the entire treatment procedure, not only to the surgery itself, but also to postoperative visits. Moreover, the patient should have access to a social support system in the form of family/friends. This social support system will enable the patient to cope in the postoperative period and will constitute another source of data on the patient's health, for instance whether there is aggravation, simulation, or dissimulation of symptoms. Moreover, the family environment will be another element of the treatment system in this difficult psychiatric diagnosis. Patients after succesful surgery (withdrawal symptoms of addiction) will have to face new challenges (i.e. starting work, returning to society), and thanks to the help of relatives this will be easier to achieve.

Another issue surrounds informed consent. Patients suffering from, for example, Korsakoff's Syndrome, would be excluded from the study due to an overly large memory loss that could influence their making an informed decision. On the other hand, in the criteria for assessing the cognitive profile, it should be taken into account that the treatment should concern the sick and not the healthy (and that therefore, some cognitive deficits can be acceptable in the qualification criteria). For this reason, it is extremely important that a multidisciplinary team participates in the patient's qualification, and that decisions about qualification are made unanimously.

One disqualification criterion would be a concomitant psychiatric diagnosis (except for mild/moderate depression, which is often a concomitant symptom in addictions). It should be considered whether the personality disorder constitutes a comorbid psychiatric diagnosis. On the one hand, a personality disorder, for instance borderline personality disorder, could be a significant hindrance to the entire research procedure, as a person with borderline personality disorder could make an impulsive decision to stop attending follow-up visits. Therefore, in our opinion, decisions in this matter should be made individually, based on the knowledge and experience of the research team. A definite criterion excluding from surgical treatment would be the presence of a brain tumour, arteriovenous malformation, or progressive neurodegenerative disease. In addition, the presence of an implanted metal device for stimulation anywhere in the body (e.g. pacemaker, spinal cord stimulator) or a metal implant in the head (e.g. aneurysm clip, cochlear implant) would also be an exclusion criterion. Another exclusion criterion would be a positive pregnancy test, as it is not known how the surgery would affect the patient and whether it might contribute to the occurrence of negative factors (e.g. stress) affecting the foetus. The last important disqualification factor for DBS surgery is significant internal burden, excluding surgery lasting up to five hours under local and thereafter general anaesthesia. Postoperatively, patients should have a follow-up visit scheduled soon afterwards. The programme should be performed by a team, as a neurosurgeon alone is untrained in interpreting different patient behaviours, while on the other hand a psychiatrist inexperienced in DBS cannot interpret properly the over-stimulation or stimulation of surrounding structures.

The result is that team work both before and after surgery is needed to care for patients with implanted DBS for addictions.

\section{Adverse events related to dbs procedures for severe refractory addiction}

The adverse events related to a DBS procedure can be divided into three categories. These complications are primarily surgery-related, i.e. haemorrhagic complications (bleeding, venous infarction), stimulation-induced complications (i.e. mood changes, the appearance of new or worsening comorbid psychiatric symptoms), and hardware-related complications (i.e. infections, erosions, the fracture of a DBS lead, or the failure of an internal pulse generator). 


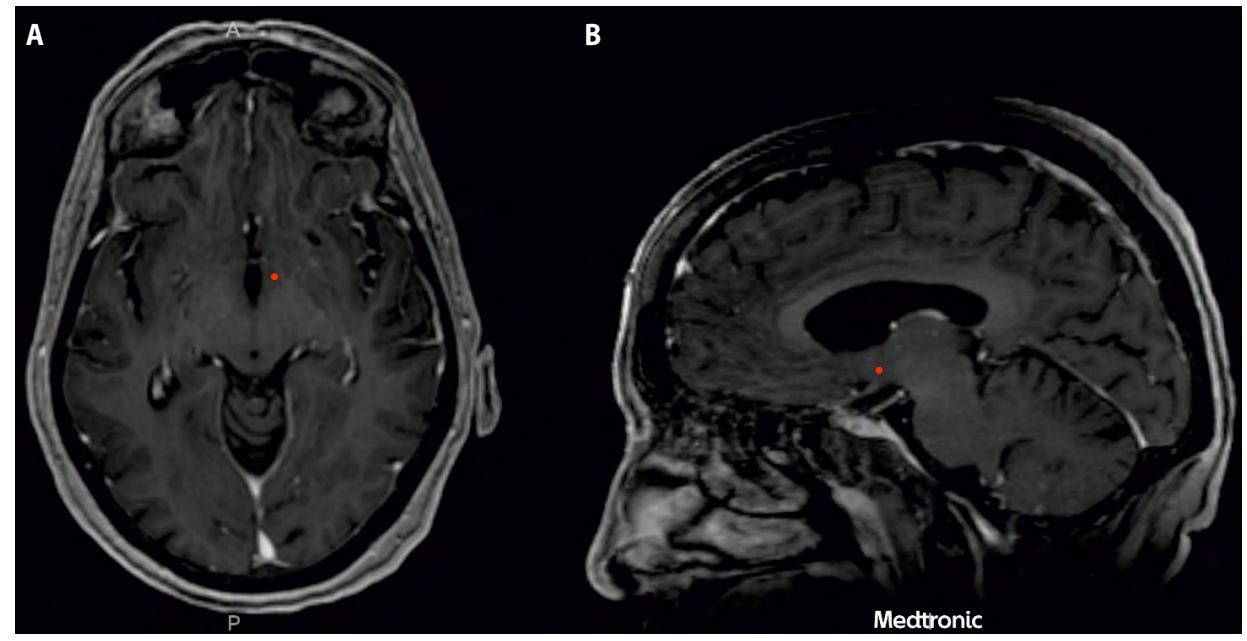

Figure 1. A. Visualisation of nucleus accumbens (NAc) in $1.5 \mathrm{MRI}$ contrast enhanced T1-weighted image in axial orientation. Right NAc is marked with red dot. NAc lies medial to ventral capsule; B. Visualization of NAc in 1.5 MRI contrast enhanced T1-weighted image in parasagittal orientation. Location of NAc is marked with red dot

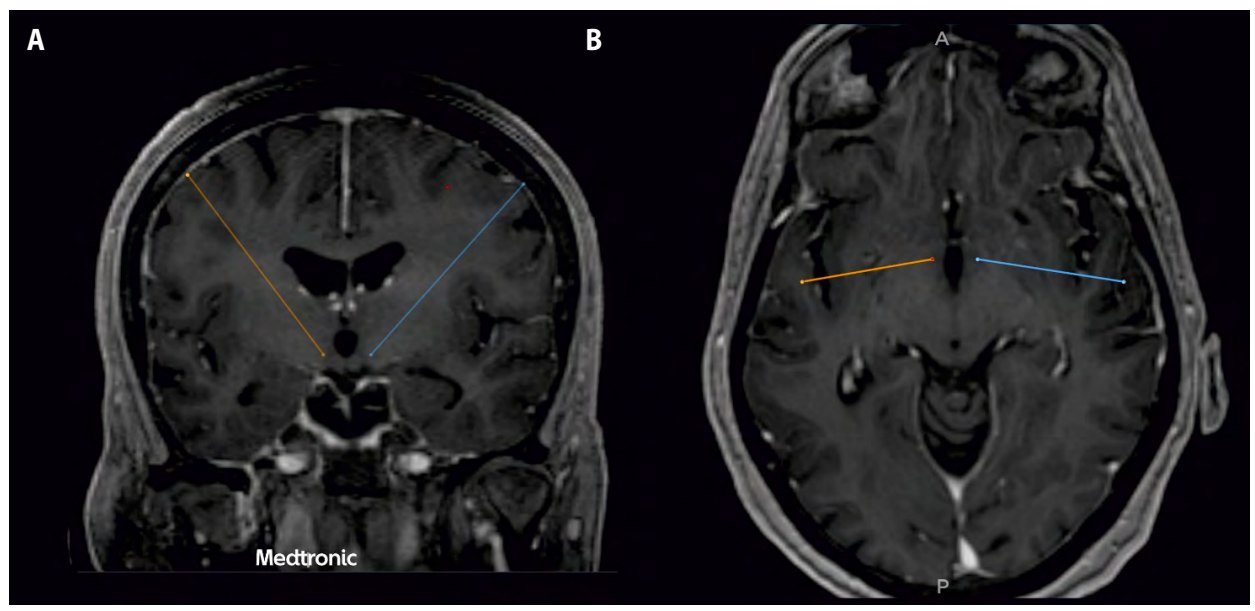

Figure 2. A. Coronal 1.5 MRI contrast enhanced T1-weighted image representing stereotactic trajectories from entry points on brain surface to NAc bilaterally. Stereotactic trajectories are planned to avoid passage of brain sulci, vessels, and ventricles to minimise intraoperative haemorrhagic complications; B. Same stereotactic trajectories shown in axial contrast enhanced T1-weighted image

A DBS procedure is usually carried out by members of a multidisciplinary team, which includes an experienced functional stereotactic team with DBS expertise in movement disorders, OCD, MDD, and other psychiatric DBS indications [34, 35]. Modern stereotactic operations are supported by navigation systems, and these have significantly reduced the number of intraoperative haemorrhagic complications by allowing the visualisation of stereotactic trajectories from the entry points at the brain surface to the stereotactic targets. This advantage in terms of preoperative planning of stereotactic trajectories enables the passing the electrodes through cerebral sulci, vessels or ventricular system to be avoided, and thereby enhances the safety of the stereotactic procedures (Fig. 1,2).

The surgery-related adverse events that have been reported have been transient, and did not result in any immediate neurological deficit or death related to a DBS procedure for addiction [20-33]. To date, only one patient treated by NAc DBS has experienced a clinically silent haemorrhagic complication located near the DBS electrode tip [28]. The most commonly reported adverse events due to NAc DBS have been stimulation-related and have appeared mostly in the early postoperative period during the optimisation of DBS stimulation settings. These stimulation-related adverse events are probably due to the overstimulation of the NAc and neighbouring structures. These have included transient hypomanic episodes, obsessive-compulsive traits, insomnia, anxiety, dizziness, agitation, irritability, and difficulties falling asleep [21, $23,28]$. All of these symptoms were transitory due to the adjustment of the stimulation parameters [21,23]. 
The main factors behind acute stimulation-related adverse events in the early postoperative period have been different stimulation parameters and the mode of stimulation $[20,22$, 24, 29-31]. Stimulation settings have not been standardised among the studies [20-33]. The stimulation parameters were adjusted throughout the studies and individualised as per patient response. In most studies, drug use and drug craving were decreased [20-25, 28, 30, 32, 33].

No hardware-related adverse events of DBS procedures for addiction, such as DBS lead fracture, or internal pulse generator malfunction, have been reported in the literature [20-33]. Interestingly, no patients suffered from skin erosion over implanted DBS hardware with a possible subsequent hardware infection. This situation may be partially explained by the still small number of patients addicted to alcohol or drugs treated by DBS with relatively short follow-up periods, reaching 1-2 years in most studies [20-23, 26, 27, 31-33].

Generally, the safety profile of DBS in patients with addictions is considered to be good, with a very low rate of mostly transient adverse events [21, 23, 25, 27, 28, 32]. Moreover, most of the patients have gained significant improvements in concomitant depressive symptoms or anxiety [21, 24, 26-28]. Moreover, DBS of the NAc, ALIC and BNST has been reported to have beneficial effects on attention, memory, sleep, and social and occupational functioning in addicted patients [20-33].

\section{Closing remarks}

The most relevant and today the most widely used DBS surgical target for the treatment of addiction is the NAc [23, 24]. It plays a central role in the reward circuit, remaining the main structure of an initial reinforcement effect to alcohol and most drug abuse (8.9). Dysfunction of the brain reward circuit which includes the NAc, the bed nucleus of stria terminalis (BNST), anterior limb of the internal capsule (ALIC), and medial forebrain bundle (MFB), is thought to underlie addiction $[10,30,36]$.

The NAc has been used in several studies to treat addiction by DBS, showing good results and preventing a relapse [20-28, 30-33]. The relatively close proximity of ALIC and BNST to NAc, structures involved in pathophysiology of several psychiatric disorders (OCD, MDD, anxiety disorders), may also play a pivotal role in the effects of DBS in addiction [26, 28-31, 33]. The ALIC contains white-matter bundles such as anterior thalamic radiation and MFB connecting the core reward circuit structures. The ALIC with its passing fibres also constitutes a promising DBS target for addiction. The anatomical neighbourhood of NAc and ALIC makes it feasible to plan a stereotactic trajectory through both structures with simultaneous neurostimulation [26, 28, 29].

Indeed, the largest to date, open-label pilot study revealed the effectiveness of both structures stimulation in preventing heroin relapse [28]. The latest case report presented a combined NAc DBS with anterior capsulotomy in a patient with polysubstance use disorder, showing convenient relapse prevention [33]. These two structures are central to the reward circuit and addiction pathophysiology, highlighting the fact that multi-site neuromodulation or a combined approach of NAc DBS with capsulotomy may be more efficacious than single-site neuromodulation $[28,33]$. The recent case report selecting the postero-medial part of NAc with neighbouring BNST showed this to be very effective in a patient with cocaine dependence [30].

Taking into account the relatively small number of individuals treated with DBS for addiction, it remains unclear whether the stimulation of the NAc itself or in combination with white-matter bundles is associated with the greater clinical benefit to patients. Shifting the target more posteriorly and ventrally closer to BNST may be more efficient for addiction, based on a clinical response to bilateral BNST for intractable OCD [37-39].

The limited worldwide experience of DBS in addiction precludes the drawing of conclusions regarding the most effective target, although the NAc is the most commonly selected target [20-25, 28, 30, 32, 33]. Moreover, the stimulation parameters and the mode of stimulation are not standardised among the studies. The stimulation parameters are corrected throughout the studies and individualised as per individual patient responses.

Addiction is a serious global problem. According to the National Survey on Drug Use and Health (NSDUH), 19.7 million American adults (aged 12 and older) battled a substance use disorder in 2017. In the same year, 8.5 million American adults suffered from both a mental health disorder and a substance use disorder, or a co-occurring disorder. Drug abuse and addiction cost American society alone more than $\$ 740$ billion annually in lost workplace productivity, healthcare expenses, and crime-related costs. These facts should lead to the promotion of more well designed studies to better understand the underlying mechanism of DBS for addiction, and to define the selection criteria for addicted patients who might benefit from DBS procedures. Addiction with comorbid mental disorders may become a new established indication for DBS in the future, in the same way that movement disorders are nowadays.

Acknowledgments: This manuscript was written without financial funding. We would like to thank Mr. Stanistaw Choński for his help in searching the literature that was used to write this manuscript.

Conflict of the interest: None.

\section{References}

1. van den Bosch LMc, Verheul R. Patients with addiction and personality disorder: Treatment outcomes and clinical implications. Curr Opin Psychiatry. 2007; 20(1): 67-71, doi: 10.1097/ YC0.0b013e328011740c, indexed in Pubmed: 17143086.

2. Di Chiara G, Bassareo V, Fenu S, et al. Dopamine and drug addiction: the nucleus accumbens shell connection. Neuropharmacology. 2004; 
47 Suppl 1: 227-241, doi: 10.1016/j.neuropharm.2004.06.032, indexed in Pubmed: 15464140.

3. Greenberg BD, Gabriels LA, Malone DA, et al. Deep brain stimulation of the ventral internal capsule/ventral striatum for obsessivecompulsive disorder: worldwide experience. Mol Psychiatry. 2010; 15(1): 64-79, doi: 10.1038/mp.2008.55, indexed in Pubmed: 18490925.

4. Nuttin B, Wu H, Mayberg H, et al. Consensus on guidelines for stereotactic neurosurgery for psychiatric disorders. J Neurol Neurosurg Psychiatry. 2014; 85(9): 1003-1008, doi: 10.1136/jnnp-2013306580, indexed in Pubmed: 24444853.

5. Zyss T, Zieba A, Hese RT, et al. [Deep brain stimulation-the newest physical method of treatment of depression]. Psychiatr Pol. 2010; 44(3): 301-317, indexed in Pubmed: 20672511.

6. Antosik-Wójcińska AZ, Święcicki Ł. The use of DBS stimulation in mental disorders - opportunities and risks. Psychiatr Pol. 2015; 49(4): 791-800, doi: 10.12740/PP/25162, indexed in Pubmed: 26488354.

7. Beszłej JA, Wieczorek T, Kobyłko A, et al. Deep brain stimulation: new possibilities for the treatment of mental disorders. Psychiatr Pol. 2019; 53(4): 789-806, doi: 10.12740/PP/OnlineFirst/103090, indexed in Pubmed: 31760410.

8. Adinoff B. Neurobiologic processes in drug reward and addiction. Harv Rev Psychiatry. 2004; 12(6): 305-320, doi: 10.1080/10673220490910844, indexed in Pubmed: 15764467.

9. Ikemoto S. Brain reward circuitry beyond the mesolimbic dopamine system: a neurobiological theory. Neurosci Biobehav Rev. 2010; 35(2): 129-150, doi: 10.1016/j.neubiorev.2010.02.001, indexed in Pubmed: 20149820.

10. Berridge KC, Kringelbach ML. Pleasure systems in the brain. Neuron. 2015; 86(3): 646-664, doi: 10.1016/j.neuron.2015.02.018, indexed in Pubmed: 25950633.

11. Olsen CM. Natural rewards, neuroplasticity, and non-drug addictions. Neuropharmacology. 2011; 61(7): 1109-1122, doi: 10.1016/j.neuropharm.2011.03.010, indexed in Pubmed: 21459101.

12. Blum K, Werner T, Carnes S, et al. Sex, drugs, and rock 'n' roll: hypothesizing common mesolimbic activation as a function of reward gene polymorphisms. J Psychoactive Drugs. 2012; 44(1): 38-55, doi: 10.1080/02791072.2012.662112, indexed in Pubmed: 22641964.

13. Jung $\mathrm{HHo}$, Kim $\mathrm{CH}$, Chang $\mathrm{JH}$, et al. Bilateral anterior cingulotomy for refractory obsessive-compulsive disorder: Long-term follow-up results. Stereotact Funct Neurosurg. 2006; 84(4): 184-189, doi: 10.1159/000095031, indexed in Pubmed: 16912517.

14. Pouratian N, Sharim J. Anterior cingulotomy for the treatment of chronic intractable pain: A systematic review. Pain Physician. 2016; 19(8): 537-550, doi: 10.36076/ppj/2016.19.537, indexed in Pubmed: 27906933.

15. Foltz EL, White LE. Pain “relief” by frontal cingulumotomy. J Neurosurg. 1962; 19: 89-100, doi: 10.3171/jns.1962.19.2.0089, indexed in Pubmed: 13893868.

16. Kanaka TS, Balasubramaniam V. Stereotactic cingulumotomy for drug addiction. Appl Neurophysiol. 1978; 41(1-4): 86-92, doi: 10.1159/000102404, indexed in Pubmed: 365103.

17. Medvedev SV, Anichkov AD, Polyakov II. Physiological mechanisms of the effectiveness of bilateral stereotactic cingulotomy against strong psychological dependence in drug addicts. Fiziol Cheloveka . 2003; 29(4): 117-123, indexed in Pubmed: 13677207.
18. Müller D, Roeder F, Orthner H. Further results of stereotaxis in the human hypothalamus in sexual deviations. First use of this operation in addiction to drugs. Neurochirurgia (Stuttg). 1973; 16(4): 113-126, doi: 10.1055/s-0028-1090504, indexed in Pubmed: 4581040.

19. Gao G, Wang $X, \mathrm{He} S$, et al. Clinical study for alleviating opiate drug psychological dependence by a method of ablating the nucleus accumbens with stereotactic surgery. Stereotact Funct Neurosurg. 2003; 81(1-4): 96-104, doi: 10.1159/000075111, indexed in Pubmed: 14742971.

20. Kuhn J, Lenartz D, Huff W, et al. Remission of alcohol dependency following deep brain stimulation of the nucleus accumbens: valuable therapeutic implications? J Neurol Neurosurg Psychiatry. 2007; 78(10): 1152-1153, doi: 10.1136/jnnp.2006.113092, indexed in Pubmed: 17878197.

21. Müller UJ, Sturm V, Voges J, et al. Successful treatment of chronic resistant alcoholism by deep brain stimulation of nucleus accumbens: first experience with three cases. Pharmacopsychiatry. 2009; 42(6): 288-291, doi: 10.1055/s-0029-1233489, indexed in Pubmed: 19924591.

22. Kuhn J, Gründler TOJ, Bauer R, et al. Successful deep brain stimulation of the nucleus accumbens in severe alcohol dependence is associated with changed performance monitoring. Addict Biol. 2011; 16(4): 620-623, doi: 10.1111/j.1369-1600.2011.00337.x, indexed in Pubmed: 21762290.

23. Voges J, Müller U, Bogerts B, et al. Deep brain stimulation surgery for alcohol addiction. World Neurosurg. 2013; 80(3-4): S28.e21S28.e31, doi: 10.1016/j.wneu.2012.07.011, indexed in Pubmed: 22824557.

24. Müller UJ, Sturm V, Voges J, et al. Nucleus accumbens deep brain stimulation for alcohol addiction - safety and clinical long-term results of a pilot trial. Pharmacopsychiatry. 2016; 49(4): 170-173, doi: 10.1055/s-0042-104507, indexed in Pubmed: 27145161.

25. Zhou H, Xu J, Jiang J. Deep brain stimulation of nucleus accumbens on heroin-seeking behaviors: a case report. Biol Psychiatry. 2011; 69(11): e41-e42, doi: 10.1016/j.biopsych.2011.02.012, indexed in Pubmed: 21489407.

26. Valencia-Alfonso CE, Luigjes J, Smolders R, et al. Effective deep brain stimulation in heroin addiction: a case report with complementary intracranial electroencephalogram. Biol Psychiatry. 2012; 71(8): e35-e37, doi: 10.1016/j.biopsych.2011.12.013, indexed in Pubmed: 22281120.

27. Kuhn J, Möller M, Treppmann JF, et al. Deep brain stimulation of the nucleus accumbens and its usefulness in severe opioid addiction. Mol Psychiatry. 2014; 19(2): 145-146, doi: 10.1038/mp.2012.196, indexed in Pubmed: 23337942.

28. Chen L, Li N, Ge S, et al. Long-term results after deep brain stimulation of nucleus accumbens and the anterior limb of the internal capsule for preventing heroin relapse: An open-label pilot study. Brain Stimul. 2019; 12(1): 175-183, doi: 10.1016/j.brs.2018.09.006, indexed in Pubmed: 30245163.

29. Zhang $C$, Huang $Y$, Zheng $F$, et al. Death from opioid overdose after deep brain stimulation: A case report. Biol Psychiatry. 2018; 83(1): e9-ee10, doi: 10.1016/j.biopsych.2017.07.018, indexed in Pubmed: 28882316.

30. Gonçalves-Ferreira A, do Couto FS, Rainha Campos A, et al. Deep brain stimulation for refractory cocaine dependence. Biol Psychiatry. 2016; 79(11): e87-e89, doi: 10.1016/j.biopsych.2015.06.023, indexed in Pubmed: 26235303.

31. Zhang $\mathrm{C}$, Wei H, Zhang Y, et al. Increased dopamine transporter levels following nucleus accumbens deep brain stimulation in methamphetamine use disorder: A case report. Brain Stimul. 2019; 12(4): 
1055-1057, doi: 10.1016/j.brs.2019.02.023, indexed in Pubmed: 30853339.

32. Ge S, Chen Y, Li N, et al. Deep brain stimulation of nucleus accumbens for methamphetamine addiction: Two case reports. World Neurosurg. 2019; 122: 512-517, doi: 10.1016/j.wneu.2018.11.056, indexed in Pubmed: 30448569.

33. Zhu R, Zhang $\mathrm{Y}$, Wang $\mathrm{T}$, et al. Deep brain stimulation of nucleus accumbens with anterior capsulotomy for drug addiction: A case report. Stereotact Funct Neurosurg. 2020; 98(5): 345-349, doi: 10.1159/000509313, indexed in Pubmed: 32846423.

34. Zrinzo L, Foltynie T, Limousin P, et al. Reducing hemorrhagic complications in functional neurosurgery: a large case series and systematic literature review. J Neurosurg. 2012; 116(1): 84-94, doi: 10.3171/2011.8.JNS101407, indexed in Pubmed: 21905798.

35. Fenoy AJ, Simpson RK. Risks of common complications in deep brain stimulation surgery: management and avoidance. J Neurosurg. 2014;
120(1): 132-139, doi: 10.3171/2013.10.JNS131225, indexed in Pubmed: 24236657.

36. Luigjes J, van den Brink W, Feenstra M, et al. Deep brain stimulation in addiction: a review of potential brain targets. Mol Psychiatry. 2012; 17(6): 572-583, doi: 10.1038/mp.2011.114, indexed in Pubmed: 21931318.

37. Luyten L, Hendrickx S, Raymaekers S, et al. Electrical stimulation in the bed nucleus of the stria terminalis alleviates severe obsessivecompulsive disorder. Mol Psychiatry. 2016; 21(9): 1272-1280, doi: 10.1038/mp.2015.124, indexed in Pubmed: 26303665.

38. Greenberg BD, Gabriels LA, Malone DA, et al. Deep brain stimulation of the ventral internal capsule/ventral striatum for obsessive-compulsive disorder: worldwide experience. Mol Psychiatry. 2010; 15(1): 64-79, doi: 10.1038/mp.2008.55, indexed in Pubmed: 18490925.

39. Naesström M, Hariz M, Strömsten L, et al. Deep brain stimulation in the bed nucleus of stria terminalis in obsessive-compulsive disorder-1-year follow-up. World Neurosurg. 2021; 149: e794e802, doi: 10.1016/j.wneu.2021.01.097, indexed in Pubmed: 33540102 . 